Carlotta Sparvoli*

\title{
Modals and negation: A semantic explanation of the modal suppletion strategy in Chinese
}

DOI 10.1515/caslar-2015-0010

Abstract: This paper aims at providing a semantic account of the mechanism informing the use of negative modals in standard Chinese. Based on the notion of modal suppletion and negation placement strategies (de Haan 1997), it will be shown that:

(i) in the negative form each modal takes on its prominent value;

(ii) this prominent modal value displays the normative source orientation (Hsieh 2005), where the Situation-oriented normative source can include the Speaker-oriented normative source and, in particular cases in the domain of Possibility, also the Subject-oriented one;

(iii) a negative modal admits different modal meanings only if there is no pragmatic conflict between them, as in the case of epistemic and nonepistemic modalities.

Moreover, I will show that in non-epistemic modalities the suppletion mechanism is related to the need for normative disambiguation and is characterized by pragmatic exclusion and semantic inclusion (respectively in the Necessity and Possibility domains). In the epistemic area, on the other hand, the mandatory suppletion of the Speaker-oriented adverbs fulfills the condition of semantic well-formedness of the sentence and, for the other epistemic items, a major role is played by the strategy of negation placement (with the result that the syntactic negation mirrors the semantic property of this modality).

Keywords: Chinese modality, modal suppletion, negation placement, deontic, anankastic

\section{Aim and theoretical framework}

One of the main difficulties for non-Chinese native speakers regarding the negation of Chinese modals involves the fact that the negative marker can be placed both before and after modals. A further complication arises when facing the choice of the proper item to be used in negative sentences. For instance, a

*Corresponding author: Carlotta Sparvoli, University of Parma, Italy, E-mail: carlotta.sparvoli@unipr.it 
positive statement in the domain of Necessity ${ }^{1}$ may equally well be conveyed by different lexical units (1a). However, when a sentential negation is inserted into the same statement, each modal takes on a specific meaning, such as Prohibition (1b) or Exemption (1c). Therefore, in order to convey the correct directive, speakers must sometimes resort to a modal suppletion. Such a strategy might be implemented by using another necessity modal (1c), by using a modal from the Possibility domain (1d, 1e) and even by shifting the negation after the modal (1d), thus also implementing a negation placement.

a. Nù yīnggāi/bìxū qù Táběi.

You should/must/have.to ${ }^{2}$ go Taipei

'You should/must go to Taipei'.

(It is required that you go to Taipei) [Deontic obligation, anankastic necessity]

b. $N \grave{\imath}$ bù yīnggāi qù Táběi.

You not should go Taipei

*You do not have to go to Taipei.

'You ought/should/must not go to Taipei.' (It is required that you do NOT go to Taipei) [Prohibition]

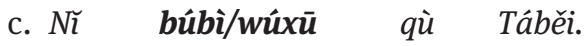

You do.not.have.to go Taipei

*You must not go to Taipei.

'You do not have to go to Taipei.' (It is NOT required that you go to Taipei) [Exemption]

d. $N \check{i}$ kĕy̌̌/néng bù qù Táběi.

You can not go Taipei

'You are allowed not go to Taipei'. (It is allowed that you do NOT go to Taipei) [Permission not to $=$ Exemption]

e. $N \grave{\imath}$ bú kĕy̆ qù Táběi.

You not can go Taipei.

'You may not go to Taipei'. (It is NOT allowed that you go to Taipei) [Permission denial $=$ Prohibition $]$

1 Necessity and Possibility, where meant as modal domains, are written with an initial capital letter. Modal notional labels are also written using capitals (the complete list is visible in the Appendix, Table 1 and 2); I capitalize the term Impossibility when it is used as a label for a notional category. A synonym could be Infeasibility.

2 Abbreviations: “.” joins the constituents of one lexical unit as in 'have.to', ASP aspectual particle; CL: classifier, DE: nominal marker 的, MA: interrogative, POT. potential complement, NEG. POT potential negative form, PROG: progressive. 
A focus on these phenomena - cross-linguistically identified as modal suppletion strategies (de Haan 1997) - makes it possible to highlight some similarities between English and Chinese modal systems. Both languages express Prohibition and Exemption through lexical units that display different scopal properties with negation, namely bù yīnggāi/yào and should/must not as well as búbi/wúxū/ búyòng and do not have to, there is no need to, as shown in (1b) and (1c). Understanding these strategies will make English L1 learners of Chinese aware that the equivalents of 'must' are different in the positive (bix $\bar{u})$ and in the negative form (bù kěy̆̌/yào). The same awareness will also help learners with a Romance language as L1, where opposite normative actions (Prohibition and Exemption) are often expressed by the same negative modal - such as the Italian 'non dovere'.

The standard classification of epistemic, deontic and dynamic modalities is not sufficiently precise for a comprehensive analysis of suppletion phenomena. Therefore, following Li Renzhi (2003), I apply here the cross-linguistic theoretical framework of van der Auwera and Plungian (1998) (Figure 1). In this inventory, a main distinction is made between epistemic and non-epistemic modalities; furthermore, the non-epistemic area is divided into participant-internal and participant-external modalities. The latter is additionally subdivided into the non-deontic and the deontic, similar to the distinction between factual necessity and moral duty discussed by Lü Shuxiang (1942) and Gao Mingkai (1948). For reasons of consistency with standard terminology, I will use the traditional labels deriving from the Finnish logician Von Wright (1951), e.g., epistemic, deontic and dynamic. Instead of non-deontic, I will use anankastic (from the Greek: ananke, 'necessity' or 'inevitability'), another term introduced by Von Wright (1963).

Finally, two caveats must be stressed. The semantic explanation provided here is based on the orientation of the normative source used in modal assessments, a parameter introduced by Hsieh Chia-Ling and defined as: "the delineation of semantic sources involved in the use of modal expressions" (2005: 53). Therefore, the focus of this paper is not the binding force of each modal, but its source orientation and the different normative actions it conveys. For this reason, the scalarity from weak to strong modals, although fruitful in the investigation of modality, is of marginal importance in this context. The equivalences between modal expressions discussed here (for instance búbì and kěyı̆ bù) must thus be understood as logical equivalences (it is not required that as the equivalent of it is allowed not to) producing the same normative action (Exemption) or pragmatic directive ('there is no need to'), despite their different expressive registers. The paper is divided into four parts: a) a schematic account of the main suppletion phenomena described in the literature; b) a semantic analysis of 


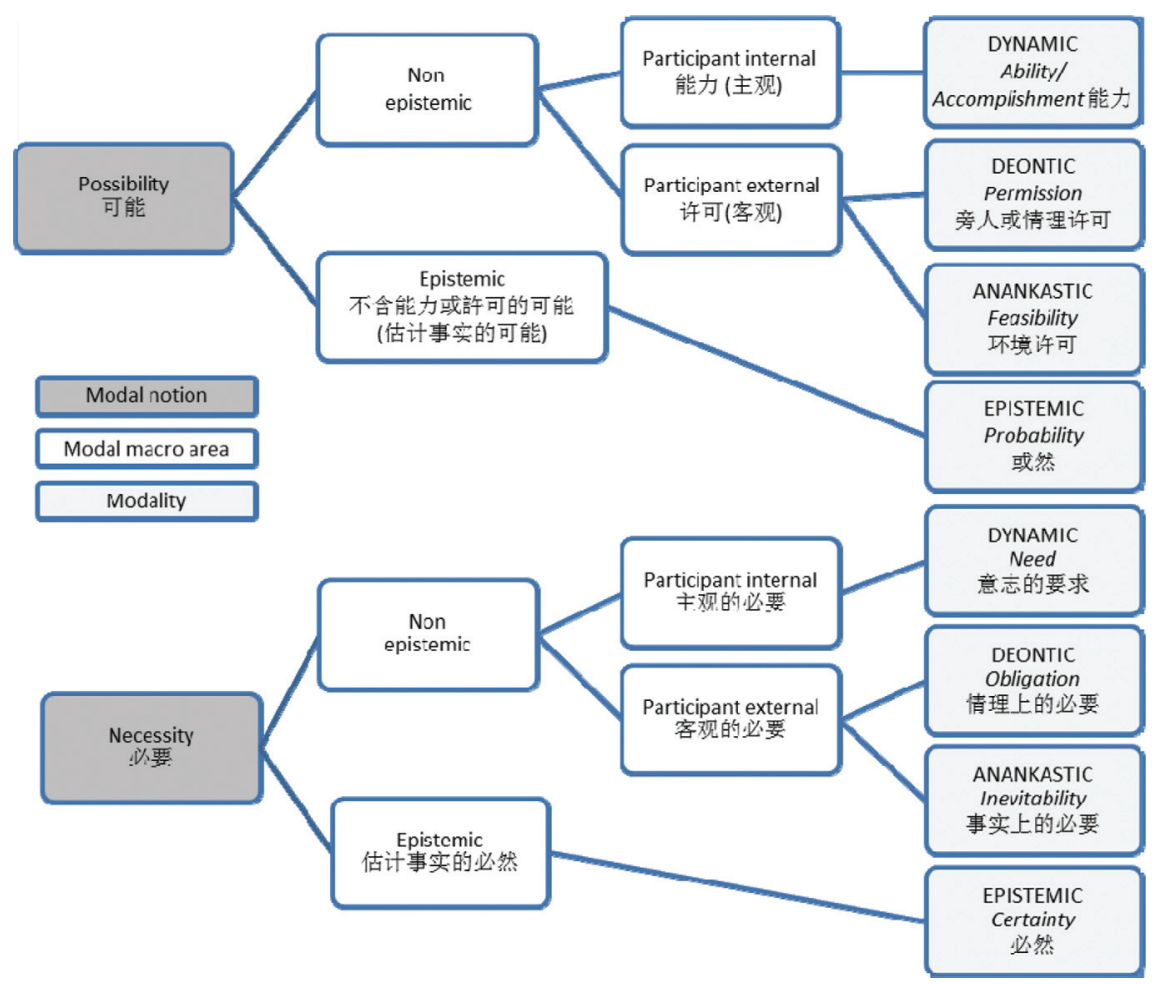

Figure 1: Modal taxonomy: Van der Auwera and Plungian (1998), and Lü Shuxiang (1942). The labels in Chinese in the figure are taken from Lü (1942), section 14.42-48 for the Possibility domain and 14.52 in the Necessity Domain. Given in brackets are visible labels that can be extrapolated from Lü's description. The labels in italics are my proposals. Feasibility and Inevitability, correspond to the basic notion of Possibility and Necessity but, in order to differentiate them from the standard modal domain labels, I have chosen a different denomination.

the non-epistemic and epistemic modalities (Sections 3, 4 and 5) with reference to the normative source orientation; c) an overall analysis based on scopal properties; and d) summary and conclusion (Sections 5 and 6).

\section{Basic facts}

The impact of negation within Chinese modal systems has been investigated since the very beginning of modern Chinese linguistics. Classical accounts are found in Wang Li (1947-1943: 140) Alleton (1984: 368) and, more recently, Li 
Renzhi (2003), but for a better understanding of the semantic explanation offered here, a brief review of the most common suppletion phenomena is in order.

1. Bù kěy̆ admitted only with the meaning of negative permission. Often, but not mandatory, replaced by bù néng. Whereas, for the other admitted modal meanings, in the negative form it is replaced by:

- bù zhíde (negative Worthiness)

- bù néng or negative potential complement (negative Ability)

- búhùi (negative Prevision)

2. Bú yào conveying different meanings according to the illocutionary force of the utterance (Alleton 1984) ${ }^{3}$ and having two admitted readings:

- in an illocutionary context, it expresses the will of the speaker to commit the hearer not to act in a certain way, an attempt to dissuade (quànzŭ 劝阻) the interlocutor to do something (pragmatically corresponding to a negative imperative), expressing Prohibition:

- $\quad$ in a descriptive context, where the hearer is not involved as a potential target of a directive, when no normative context can be retrieved and no ambiguities can arise between 'do not!' and 'do not want', it can be used with a volitional sense, meaning "do not want”. The most common form of this case is when the speaker and subject are the same person, as in : 'Wo bu yao xizao!!!' 'I do not want/need to wash' (Alleton 1984: 376).

Bú yào replaced by bù xiăng:

- With the meaning of negative volition in a context which could have an illocutionary or a normative reading. In these cases, the suppletion of bú yào with bùxiăng makes it possible to disambiguate a directive from a descriptive sentence or a Prohibition (bú yào) from a generic negative will (bùxiăng). (Alleton 1984: 377).

Bú yào replaced by bú huì:

- When used as an aspectual marker (Chen and Saillard 2011), meaning futurity.

3. Búbì, búyòng and wúxū as the only admitted negative form of bìxù, expressing Exemption, that is, a normative meaning the opposite of Prohibition, the latter being conveyed by bù yīnggāi.

3 Notionally speaking, yào can be located in a grey zone between Necessity and Desire, which in the modal taxonomy that I refer to "pertains more to illocutionary type" (Van der Auwera and Plungian 1998: 83). The same can be said of the negative imperative, which is also related to the illocutionary level, i.e., to a level of abstraction higher then modality. 
Moreover, in the literature, other data are found which are equally well-known but which are the object of a less extensive investigation and which refer to the mechanism labeled by de Hann (1997) as negation placement.

4. Bīxù bù equivalent to bù yīnggāi (Prohibition), whereas yīnggāi bù cannot be used for conveying an Exemption.

5. Yīnggāi bù having only an epistemic meaning (negative Prevision) and bù yīnggāi having preferably a deontic one.

6. Huì bù used only with epistemic meaning.

7. Bú huì expressing:

- $\quad$ negative Ability (as a modal marker); or

- Futurity [as an aspectual marker (Chen and Saillard 2011)].

8. Kĕndìng behaving as a positive polarity item (Ernst 2008, 2009), thus admitting only internal negation ('Certainty that not'), for external negation (Uncertainty) replaced by bù yíding (hui) or by the Possibility item bú huì/kĕnéng.

Finally, the following account is given concerning double negation:

9. Bú huì bù having only an epistemic interpretation, and shifting from Possibility to Necessity.

10. Bù yīnggāi bù, having preferably a deontic reading and remaining in the Necessity domain (without shifting to Possibility, as would be expected for the double negation of a necessity modal).

11. Neg + bìxū neg, shifting from Necessity to Possibility. On this regard, it must be noted that constructions of the type fëi děi ... bùkě, though apparently having the structure of búbì ... bù, do not shift to possibility. They simply emphasize a meaning of necessity, and following Li (1924: 104) and Lü (2002-1942: 256), are here interpreted as covert hypothetical constructions, not as a true double negation.

\section{Pragmatic opposition for non-epistemic necessity}

\subsection{Exemption vs. Prohibition ( $\square / \square \neg)$}

Generally speaking, the insertion of negation confers a specific pragmatic meaning to a proposition, in some cases producing a shift from the propositional to the illocutionary level, thus generating a speech act. More specifically - as observed in deontic logic (Von Wright 1963: 136ff) and in Chinese linguistics 
investigation (Li Jinxi 1924) - once a normative statement is turned to the negative form, it produces two antithetic and irreducible sentences, either Prohibition ('it is necessary not to') or Exemption ('it is not necessary to'), either bùkě 不可 ('it is not allowed [possible] to') or kěbù ('it is allowed [possible] not to') (Li 1998-1924: 104-105). Concerning the feature of negative normative sentence, starting from the observation that when we say "bù gāi qù", actually we are saying: "gāi bú qù", Lü Shuxiang (2002-1942: 257) highlighted the asymmetry between syntactic and semantic negation occurring in the deontic domain. Using the diamond as a notation for possibility, the square for necessity and the angled dash for negation, these concepts can be described as follows:

\section{1c) PROHIBITION: \\ You are OBLIGED not to 不可 $\square\urcorner=\neg \diamond$ Modal $>$ negation must/should NOT bù yīnggāi}

1d) EXEMPTION:

You are FREE not to 可不 $\neg \square=\diamond$ Negation $>$ modal DO NOT have to búbi

Such behavior is visible with different patterns in the participant-external area (deontic and anankastic modalities). (1) provides an instruction ('go to Taipei') which can be anchored to some rule or principles that the speaker deems to be meaningful - this is what Lü (1942) labeled as qinglĭ shang de bìyào 情理上的必要 - or which can be related to some property of the state of affairs - and this is what Lü would term as shishíshang de bìào 事实上的必要. In other words, applying the notion introduced by Hsieh Chia-Ling (2005), the normative source of (1) could be Speaker-oriented, which I gloss as follows: "considering the principles, rules and customs that I, the speaker, deem as valid, it is appropriate that you go to Taipei". ${ }^{4}$ On the other hand, (1) could also be Situation-oriented, that is: "considering the objective and contingent scenario, whether you/I like it or not, it is necessary (inevitable) that you go to Taipei".

Whatever the orientation of the normative source is, in the declarative form the result is the same: "if you listen to what I say, you go to Taiwan". As this is

\footnotetext{
4 A similar point of view is suggested by Huddleston for subjective deontic modalities, having "the speaker as the deontic source, the one who imposes obligation or grants permission" (2002: 183, cit. in Narrog 2012: 29). I consider the speaker to be the normative source even when there is a connection to a rule or an obligation. In fact such a reference is an implicit commitment by the speaker to this set of values. In other words, a criminal would not refer to the law when deciding if an action is desirable or not, preferring, perhaps, the code of the underworld, the only ethic he is prone to acknowledge.
} 
the case, we can use both yinggāi and bìxū, or děi, and, in an illocutionary context, characterized by familiarity, such as between mother and child, we could use yào (Alleton 1984: 304). This changes once the declarative statement is turned into a negative one. In that case, two irreducible normative concepts stem from (1), as shown in (1.b) and (1.c) in the table below and, for disambiguation, two options are available: i) changing the position of the negation; and ii) resorting to another modal capable of conveying that specific meaning. This is the logic underlining the mechanism of negation placement (i), as in bìxū bù equivalent of bù yinggāai, and the mechanism of suppletion (ii), as in bù yīnggāi replaced by búbì/wúxū in (1.c) (Figure 2).

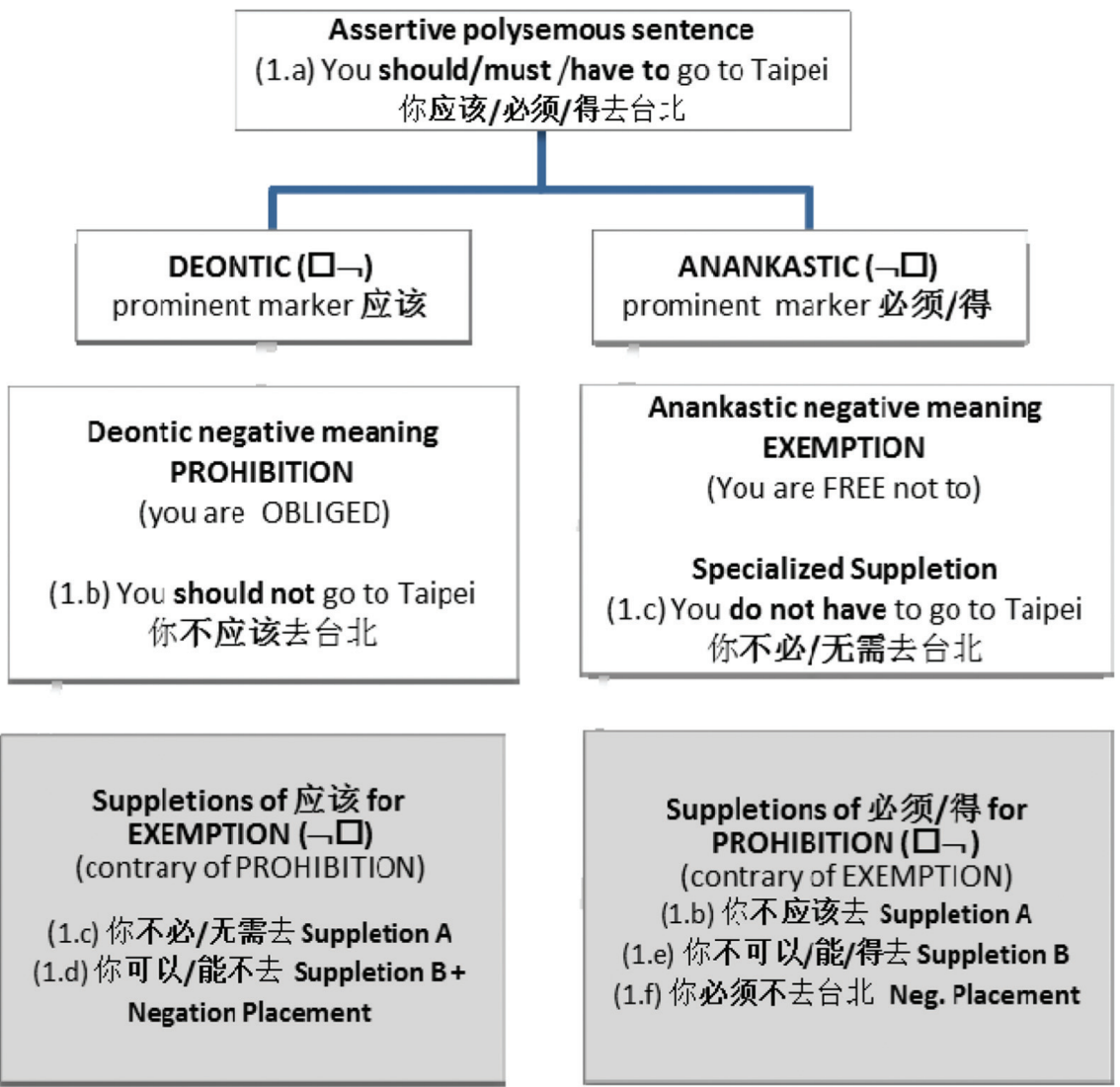

Figure 2: Negative normative action (participant-external modality, Necessity Domain). Following Li Renzhi (2003: 297ss), the suppletion area can be subdivided into two classes: suppletion A (resort to another modal in the same domain) and suppletion B (resort to a different modal in another domain). 


\section{Semantic inclusion for non-epistemic possibility}

\subsection{General impossibility vs. Permission denial $(\neg \diamond / \neg 0)$}

Whereas in the Necessity domain the two negative statements are irreducible opposites, this is not the case for Possibility. By turning (2) to the negative form we obtain two participant-external modal expressions which convey the same content: "whatever is the hearer's point of view, he will not be in a position to go to Taipei". But, only one of them (2d) (Figure 3) actually corresponds to a normative concept and specifies the source which made the speaker claim such impossibility.

(2) Nũ néng/kěyı̌ qù $\quad$ Táiběi [anankastic?, deontic?]
You can/may go to Taipei
'You can/may go to Taipei.'

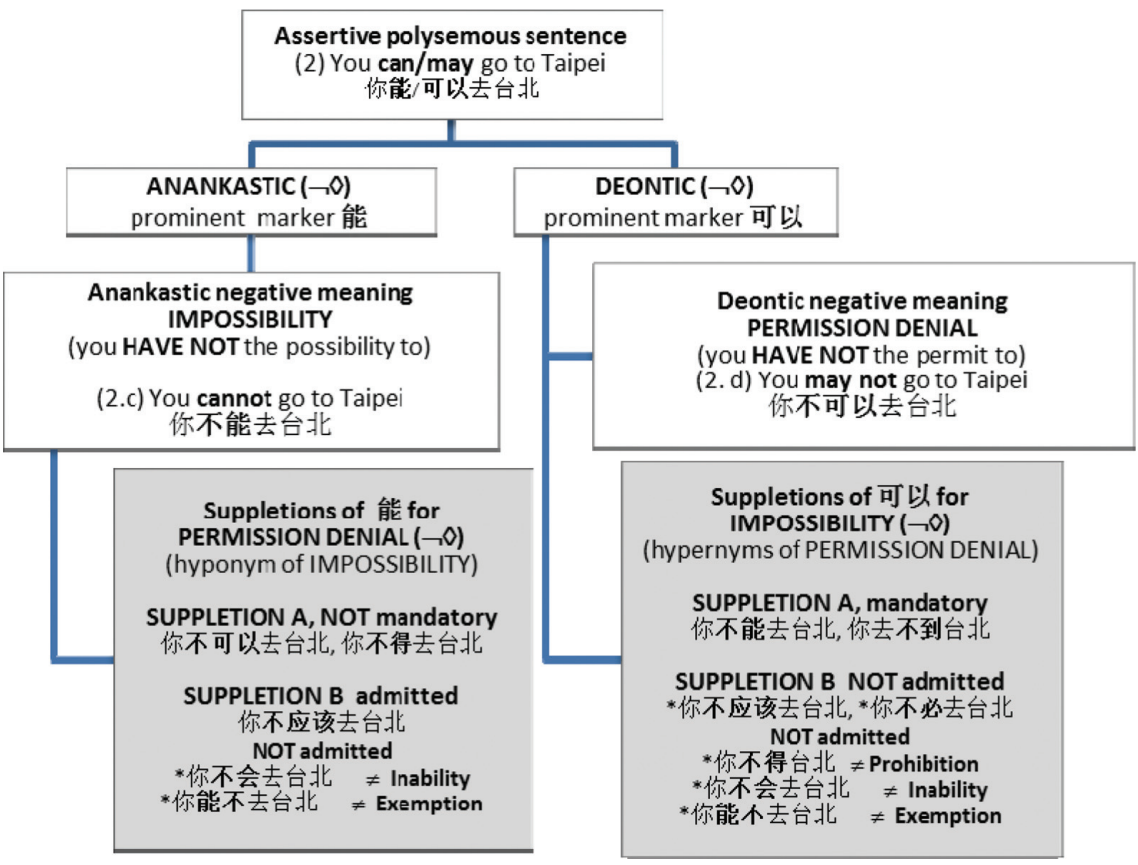

Figure 3: Negative normative action: participant-external modality, Possibility domain. 
In fact, bù kěyı̆ undoubtedly tells us that the obstacle to going to Taipei is a Permission denial. It is not relevant if the speaker is or is not entitled to deny such a permission. In both cases he is giving voice to a rationale that he deems to be valid in that scenario. ${ }^{5}$ For this reason I ascribe the normative source of (2d) to the "Speaker-oriented" category, which is grounded on a rationale assessed by the speaker (and which is not based on the evaluation of the feasibility of that action). On the other hand, the general Impossibility (2c) to carry out a given task (going to Taipei) is connected to some aspect inherent to the situation, such as a typhoon or any other event that might be contingently preventing the actualization of the given state of affairs. By using a formal notation based on the notion of Possibility, ${ }^{6}$ it then becomes evident that Exemption and Prohibition are contraries, whereas Permission denial and Impossibility are equivalents. Still, though logical equivalents, bù néng and bùkěy̆ overlap only partially. In other words, Permission denial (bù kěy̆) can be conceived as a specific case of impossibility, and practical impossibility (bù néng) can be conceived as an extended meaning of Permission denial (Figure 3).

From the perspective of Deontic Mental Models Theory (Beller 2001), we could assume that the deontic reasoning underlying the partial overlap of these modals attests to the tendency to infer as unfeasible or impossible (bù néng), what is not permitted (bù kěy̆). Alternatively, based on the studies on the psychology of negative sentences, it could be claimed that bù néng conveys the normative concept of Permission denial somehow mitigating the "prohibitive connotation"7 of bùkěy̌. The distinction between these two classes of possibility is of course sensitive to a number of factors which do not directly pertain to typological linguistics, still, the relevant point here is that 'non-permissibility' (deontic) can be considered as a subset of 'general impossibility' (anankastic), but the same relationship does not obtain the other way round. In other words, these two notions are hierarchically related as hypernyms-hyponyms, where Impossibility (2c) is a super-ordinate to Permission denial (2d) (Figure 4).

5 Lü (2002-1942: 247) actually makes a distinction between 'permission deriving from a third person, the environment or from a rationale' pángrén huò huánjìng huò qínglı̆ xŭkě. In my reading, when the speaker refers permission to a third person or to a principle, he is actually enforcing such a principle (or the person issuing the permit) as an acceptable normative source. 6 This notation is actually equivalent to Li Jinxi (1998-1924: 104-105) use of kě as a primitive notion.

7 For an account on those investigations and on the implicit emotive content of negativity, refer to Horn (1989: 168ff). 


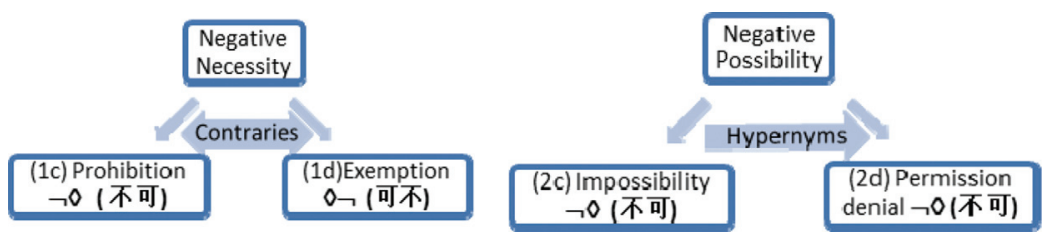

Figure 4: Semantic relations in the Necessity and Possibility domains (non-epistemic).

In this case, bù néng (Situation-oriented normative source) can include the meaning of bù kěyı̆ (Speaker-oriented), but bù kěy̆ covers just one specific area of the domain of bù néng, therefore the former does not exhaust the meaning of the latter. For this reason, as highlighted by Alleton (1984: 371), bù néng can be used with the meaning of bù kěyı̆ when an explicit reference to a definite situation is present, such as a circumstantial marker (zài zhèr) in (3a). Without it, bù néng shifts to the participant-internal area (dynamic) expressing Inability or Failure.

(3) a. Zài zhèr wŏ bù néng/kěyĭ shuō zhōngwén. (Alleton 1984: 371) In here I not can/may speak Chinese 'I may not speak Chinese here' [deontic possibility, Permission denial]

b. Wŏ bù néng shuō zhōngwén. (idem) I not can speak Chinese

'I cannot speak Chinese' [dynamic possibility, Failure]

Contrasting with the relatively extended description provided by bù néng + circumstantial marker (for instance zài zhèr in 3.a), a common feature of sentences with permission interpretation is "their brevity, there being no need for lengthy explanation as the speaker already knows the participant and the circumstances of the action" (Siemund 2001: 1031). This aspect is visible for bù kěy̆, whereas in permissive expressions bù néng is normally used with a definite reference, as in (4), confirming the above-mentioned observation by Alleton.

(4) Bù néng zhèyàng.

Not possible this-manner

'This is not allowed'. Equivalent of: bù kěy [Permission denial, *Inability, *Impossibility]

Similarly, as underlined by Teng (1977: 77), bù kěy̆ admits a sentential phrase subject (5a), but this is not possible with bù néng and bú huì (5b). The same holds, respectively, for bù yìnggāi with a deontic reading (5c) - not with 
epistemic reading as in (5d) - and for búbì (5e). Finally, these constructions are grammatical only with the negative marker bù, without it they sound odd (5f).
a. Nĩ zhèyàng zuò bù kěy̌̆/xíng.
(Teng 1977: 77)
You this-manner do not may
'Your doing this like this is not allowed.' [deontic possibility]
b. * Nǐ zhèyàng zuò bù néng/huì.
c. $N \check{\imath}$ zhèyàng zuò bù yīnggāi.
You this-manner do not should
'For you to do it this way is (un)acceptable.' [deontic necessity]
(Lin and Tang 1995: 56, cit. in Huang 2009: 526)
d. $\neq$ 'Certainly you will not act this way.' [epistemic]
e. * Nĭ zhèyàng zuò búbì. [anankastic]
f. ? Nǐ zhèyàng zuò kěy̌̃ /xíng/yīnggāi.

\subsection{Participant-internal possibility and actuality}

With regards to the relations between Inability and Impossibility, paraphrasing Teng (1977:75), we could say that the former highlights a "state of the Patient", whereas the latter stresses a "permissibility event". Since they refer to different thematic roles, Inability and Impossibility are not hierarchically related. Impossibility can instead be referred to a property which is simultaneously inherent to the subject (participant-internal) and related to a permissibility event. It thus shifts to the dynamic modality, and more specifically to the negative form of the class termed by van der Auwera and Plungian (1998: 104) as 'participant-internal actuality', expressing the idea of "fail to succeed", "not manage to", which I label as Failure. In this sense, differently from Inability, Failure can be considered as a hyponym of the anankastic Impossibility (Figure 5).

The contrast between negative ability meant as a state (Inability) or as an event (Failure) is cross- linguistically relevant, for instance, in Italian it is lexicalized by: non sapere ('not to be able to', bú hui) vs. non riuscire a ('do not succeed in/manage to', bù néng or negative potential complement). These two different modal meanings pertain to the same class, i.e., dynamic, but are characterized by different source orientation, being the Subject for Inability and the Situation for Failure.

As outlined above, with reference to the thematic role and the source orientation, the participant-internal modality is twofold, in one case it is referred to as an ability intrinsic to the participant (Ability/Inability, Subject-oriented source), in the 


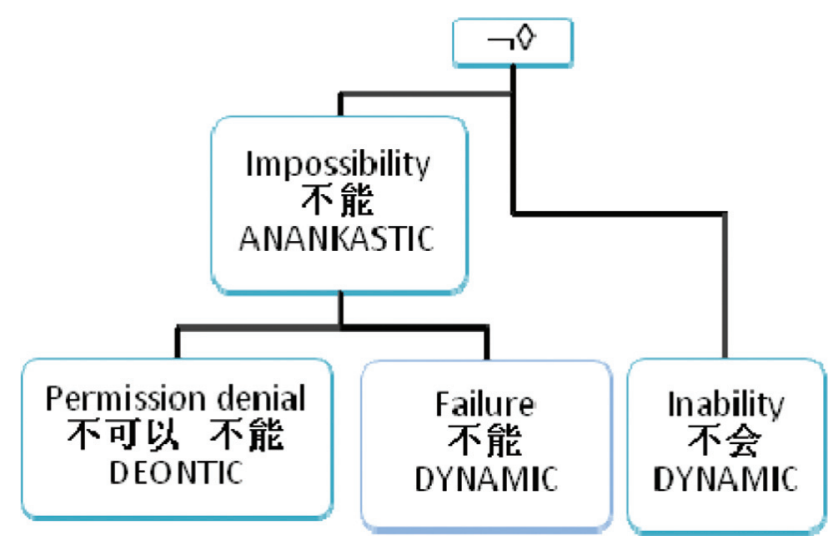

Figure 5: External negation in the Possibility domain.

other it expresses the extent to which the participant manages (or does not manage) to actualize the state of affairs notwithstanding a challenging situation or task (Accomplishment/Failure, Situation-oriented). The latter class is compatible with internal negation, the former is not. In fact, it is intuitively understood that a 'claim of negative ability' is a self-contradictory notion, but the same does not hold for the 'ability to refrain from doing something', simply speaking, 'Possibility not to', néng bù. For this reason, the internal negation is not admitted with huì meaning 'acquired ability' but is acceptable with néng bù (just as in Italian, 'sapere non ...'sounds odd, whereas 'riuscire a non' is accepted), as in the example below (Figure 6):

(6) Luòtuo néng hăo jì tiān bù chī dōngxi.

camel can quite a.few days not eat thing

'Camel can eat nothing for quite a few days.'[dynamic, Ability not to (Ability to refrain from)]

* Luòtuo huì hăo jǐ tiān bù chī dōngxi.

(Zhu 1982: 62, cit. in Li 2003: 186)

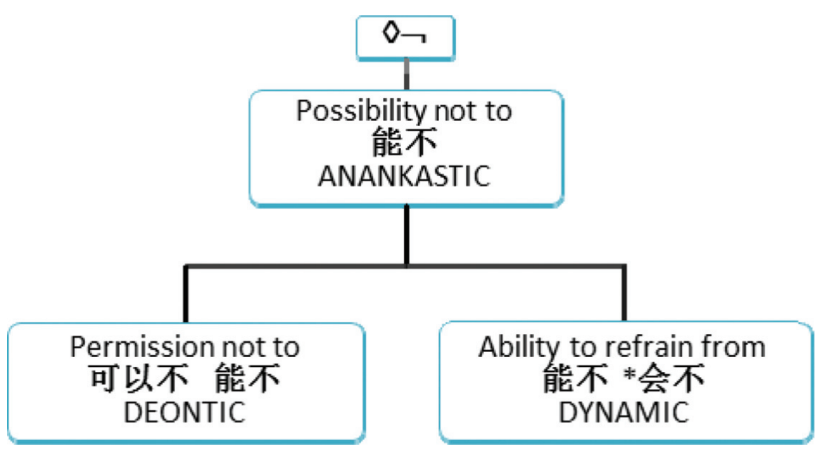

Figure 6: Internal negation in the Possibility domain. 
Without the circumstantial marker (hăojí tiān) the sentence would sound odd, confirming that the 'Ability to refrain from' is acceptable only with reference to a Situation, a circumstance in which the subject can display a specific negative ability. From a pragmatic perspective, all these uses of néng bù conveys to the hearer the same content, that is, the 'Possibility not to'. Therefore, this Situationoriented formula occurs as a suppletive form for a modal having a semantic domain which is not compatible with the internal negation, such as the hui meaning of 'acquired ability'.

In conclusion, anankastic and deontic possibility modals admit a reading of the type: 'it is possible not to' $\left(\nabla_{\neg}\right)$. But, for the same reason I have underlined with reference to the contrast bù néng vs. bù kěy̆, the semantic domain of néng bù is wider than that of kěyı̆ bù. Whereas the latter suggests a permission not to do something, the former expresses the general possibility not to do something which, based on context, can be related to the release from an obligation (being a synonym of kěyı̆ bù) or to a suppletive form of huì bù, indicating a negative capacity, as in (6).

\subsection{A transmodal item}

To conclude this survey in the Possibility domain, mention must be made of the different roles assigned to the homograph 得 which, by occurring with different morpho-syntactic features, is a prominent marker of three modal categories ${ }^{8}$ and conveys four different modal meanings. And it does so displaying for each reading a different negative construction.

Preverbal constructions:

- Necessity domain: incompatibility with negation (děi, anankastic, Inevitability);

- Possibility domain: mandatory negation (bù dé, deontic, Prohibition).

Postverbal constructions:

- Stressed negation without de ellipsis ('V1 de bù V2', dynamic, Inability);

- Unstressed negation with de ellipsis ('V1 bu V2', dynamic, Failure).

(7) Făyŭ wŏ jiăng de bù tài hăo.

French I speak can not too well.

'I cannot speak French very well.'

8 Děi occurs also for epistemic and deontic necessity, but it is not a prominent marker of these modalities. 
(8) Qiánbian de rén dāng zhe wǒ, kàn bu jiàn hēibăn shang In.front DEpeople obstruct SP I see not see blackboard on de hànzì.

DE character.

'There are people standing in front of me, I cannot see the writing on the blackboard.'

As underlined in Section 4.2, this different modal value of the post-verbal constructions (corresponding respectively to the degree and to the potential complement) stands out clearly also with reference to their different ordering source. For the degree complement (V1 de bù V2) it generally refers to the Subject, as in (7). The potential complement (V1 bu V2) can also be dependent on the Situation, as visible in (8).

\section{Syntactic transparency for epistemic modalities}

With regards to the inventory of Chinese epistemic modals, it is generally accepted that epistemic necessity can be expressed via gāi, yīnggāi, yào, děi, but only gāi and yīnggāi can be considered prominent markers (Li 2003: 176ff) and are capable of expressing a negative prevision, here labeled as 'Certainty that not', equivalent to 'it is the case that not, $\square$ '. Moreover there is a set of epistemic adverbs, among which the most common are yiding 'necessarily', 'certainly', kěndìng 'definitely' and zhŭn 'surely' (having also a homograph verb, meaning 'to allow'). These items display different scopal properties, viz. a) only yídìng can take scope both over and under negation, b) kĕndìng behaves as a positive polarity item, and c) the full-fledged modals have semantic scope over negation, which sometimes is iconically mirrored in the syntactical order, and sometimes not (e.g., when the negation is 'misplaced' before the modals, as in bù yinggāi). I will describe the suppletion phenomena that occurs with the full-fledged modal in Section 5.3, but will first focus on the epistemic adverbs, starting from a cross-linguistic observation.

In order to turn a sentence like (9.a) into negative form, given the "absence of a negative modal sentence adverb" (9.b), we need to resort to predicative epistemic modal adjectives (Nuyts 2001: 97) as in (9.c) or use the only necessity modal which is compatible with sentential negation, viz. 'necessarily' (9.c).

(9) a. 'Tomorrow it will certainly rain.' [Certainty]

b. *'Tomorrow it will not certainly rain.'

c. 'It is not certain that tomorrow will rain'. [Uncertainty, $\neg \square$ ]

d. = 'Tomorrow it will not necessarily rain.' 
As shown by Ernst (2008) this behavior can be observed also in Chinese. For instance, the negative form of (10.a) is possible only implementing a suppletion strategy, as in (10.b) and (10.d).

\author{
a. Míngtiān kĕndìng xià yŭ. \\ Tomorrow certainly fall rain. \\ 'Tomorrow it will certainly rain.' [Certainty] \\ b. Míngtiān bù yídìng xià yŭ. \\ Tomorrow not necessarily fall rain \\ 'Tomorrow it will not necessarily rain.' [Uncertainty, $\square$ ] \\ c. ${ }^{*}$ Míngtiān bù kĕndìng xiàyŭ. \\ d. Mingtiān kĕnéng bú xià yŭ. \\ Tomorrow be.likely not fall rain \\ 'It's likely that tomorrow it will not rain.' [Probability that not, $\neg \diamond$ ] \\ e. $\neq$ Mingtiān kĕndìng bú xià yŭ. \\ Tomorrow certainly not fall rain \\ 'Tomorrow it will certainly not rain.' [Certainty that not, $\square$ ]
}

The semantics underlying this phenomenon must be framed within the distinctive traits of epistemic modality. In this regard, the uncontroversial features described in the relevant literature are as follows:

a. There is a sharp distinction between the epistemic and the non-epistemic areas, being that the former tends to take scope over all propositional operators, and thus is often extra-propositional (Drubig 2001: 44);

b. Epistemic modality is very closely linked to evidentiality, viz. "the source of evidence the speaker has for his or her statement” (de Haan 2006: 57);

c. Epistemic modality tends to be twofold between subjectivity and objectivity, depending on the evidence on which the speaker bases his or her inference. In other words, some epistemic modals are capable of somehow “objectifying”, kèguānhuà 客观化, the speaker’s assessment (Peng and Liu 2012).

Applying the parameter of the orientation of the semantic source, it can be claimed that the subjective and objective epistemic classes are, respectively, Speaker- and Situation-oriented. In the former the inference is based more on the subject's intuition, whereas the latter relies somehow on objective evidence. In next section we will see how the different evidential nuances are mirrored in the semantic source orientation of epistemic adverbs and how it affects suppletion. 


\subsection{Speaker-oriented vs. situation-oriented markers}

As shown cross-linguistically, orientation is part of the lexical specification. More specifically, a natural class was singled out and labeled as "Speakeroriented Adverbs” including evidential adverbs like 'supposedly', 'evidently', 'obviously', etc. They represent the "speaker's subjective commitment to the truth of the proposition represented by the adverb, which is incompatible with the falsity of the same proposition required by negation". Given their "veridicality" (Ernst 2008, based on Giannakidou 1999, 2001), they require the proposition to be true, cannot occur in the scope of negation and are incompatible with both morphological and constituent negation. Moreover, other adverbs are found which can have scope under negation and show prefix negation, as 'necessarily' ('unnecessarily') and 'possibly', ('impossibly') (Drubig 2001: 8-9). The above-mentioned class of Speaker-oriented adverbs (behaving as positive polarity items) is also found in Chinese where it includes kĕnding ('certainly') and excludes yíding ('definitely’, 'necessarily’) (Ernst 2008, 2009). The latter, with kĕnéng (to be likely), is the only epistemic modal capable of taking scope both over and under negation (Hsiao and Lin 2011), just like 'necessarily' and 'possibly'.

The positive polarity constraint of kĕnding can be bypassed only in specific conditions, as in modal combination (bù néng kĕndìng) or in a 'shì... de construction' (bú shì kĕndìng de), but in general this adverb behaves as a "veridical" world. Therefore, returning to the analysis of (10), kĕnding is semantically incompatible with direct negation (10.c). For this reason, with external negation a suppletive form is necessary (10.b), whereas no restrictions are imposed for the internal one (10.d), expressing 'Certainty that not'.

Before relating this "veridical" feature to the suppletion phenomenon, we need to single out the specific source orientation of yíding and kĕnéng, as opposed to the uncontroversial Speaker-oriented feature of the epistemic positive polarity item. The polarity of kĕnding can be explained with reference to its specific evidential nuance, since it expresses an inference "based upon the inner world of the speaker, his feelings and sensations and [...] does not necessarily imply an emphasis on the evidence he avails himself of" (Peng 2007: 431). Resorting to yíding instead sometimes makes it possible to express an objective evidential nuance and is therefore Situation-oriented, as in the French proverb below (having a deontic flavor, incompatible with kĕndìng):

$$
\begin{array}{llll}
\text { a. Mén yídìng } & k a \bar{i} \text { huò guān zhe. (Peng and Liu 2012) } \\
\text { Door necessarily open or closed ASP } &
\end{array}
$$


'Il faut qu'une porte soit ouverte ou fermée.'

'A door is either open or shut.'

b. *Mén kĕndìng kāi huò guān zhe.

The objective connotation sometimes displayed by yiding can also be found in kĕnéng ('to be likely', 'probably'). In certain contexts, and especially in combination with yŏu 有 'exist', it is capable of objectifying the speaker's assessment (Peng and Liu 2012). Applying the parameter of the modal source orientation, it can be claimed kěnéng and yídìng are Situation-oriented. Moreover, another feature shared by them is that they admit both internal and external semantic negation and can occur in double negation, thus shifting to the other domain (Possibility for yídìng and Necessity for kĕnéng). Paraphrasing Horn (1989: 236), we can say that these two items fully display the interdefinability of logical duals, a feature which is hard to find for other epistemic modals.

So far, I have underlined that there are epistemic adverbs that do not tolerate being preceded immediately by negation resorting to the notion of veridicality and highlighting the scopal and semantic properties that are linked to this. Once again, the suppletion of a Speaker-oriented item by a Situationoriented one (bù yídìng replacing bù kĕndìng) can be observed, but unlike the case of anankastic and deontic possibility (bù néng replacing bù kĕyŭ), this is a mandatory suppletion. If not implemented, due to the semantic paradox of a "negated veridical word", the sentence would be grammatically ill-formed.

The positive polarity of many epistemic adverbs also confirms the tendency of the epistemic modals to take scope over all propositional operators. In the next section I will show how this feature applies to verbal modals (gāi, yinggāi and hui), highlighting that it is mirrored in the negation placement strategy. Moreover, I will try to tackle the question of whether the strategy of negation placement is of any help to disambiguate the two antagonistic meanings, viz. epistemic vs. deontic, which in Chinese as in many other languages are denoted by the same modal (de Haan 1997: 8).

\subsection{Negative prevision or negative obligation?}

A sentence like (12.a), having an epistemic necessity modal, an eventive predicate and a temporal marker, after the insertion of the sentential negation, becomes infelicitous. Bù zhŭn admits only a deontic reading ('it is not allowed that'), děi is not compatible with negation and, in a similar sentence, bù yīnggāi would sound weird. In other words, yinggāi bù would be the most felicitous 
negative form. As an alternative, we can use the suppletive form from the Possibility domain but only bù kĕnéng is felicitous (12.c), since bù huì would shift to futurity (12.e), which in the present theoretical framework is considered a premodal or a postmodal usage (Van der Auwera and Plungian 1998: 97). Once more, also with hui, we could preserve the epistemic reading by placing the negation after the modal, but this strategy is normally used in interrogative sentences (12.f).
a. Míngtiān yīnggāi/dĕi/zhŭn xià yŭ.
Tomorrow should/certainly/must fall rain.
'Tomorrow should/must/for.sure rain.' [Certainty]

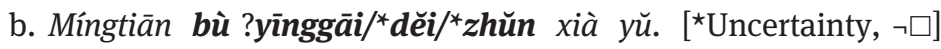
c. Mingtiān bù kĕnéng xià yŭ.
Tomorrow not be.likely fall rain
'It is not likely that tomorrow it will rain.' [Improbability, $\neg \diamond$ ]
d. Mingtiān yīnggāi bù xià yŭ.
Tomorrow should not fall rain
'Tomorrow it should not rain.' [Certainty that not, $\square_{\neg}$ ]
e. Mingtiān bú huì xià yŭ.
Tomorrow not will fall rain
₹'Tomorrow it will not rain.' [Negative futurity]
f. Mingtiān huì bú xià yŭ ma?
Tomorrow may not fall rain Ma?
'Tomorrow it may not rain?' [Probability that not, $\left.\diamond_{\neg}\right]$

The necessity modals listed in (12.a) are all polysemous and each of them, if negated, conveys a normative action (Prohibition and Permission denial). Therefore, confirming the link between suppletion and disambiguation of different normative meaning, in the negative form none of them admit an epistemic reading. However, there is an important exception: yinggai, and even if it is true that in a sentence as (12) its more natural use would be with negation placement (12.d), there are also other constructions (especially with stative predicate, as in (13) and (14)) in which it admits an epistemic reading with external negation. Concerning the scopal properties of prominent epistemic modals, there is ample literature confirming that both gāi and yinggāi have wide scope (inter ali: Tsang 1981: 75, Hsiao and Lin 2011: 3). Tsang suggests that gāi, if preceded by negation, admits only a deontic reading, but his claim is challenged by Li (2003), with this counter-example: 
(13) Zhè běn shū bù gāi shì tā de.

(Li 2003: 185)

This CL book not should be he DE.

'This book shouldn’t be his.' [epistemic reading, illocutionary modifier, $\square \neg$ ]

Moreover, a challenge to the wide scope of yinggāi is offered by Wang (2003) who denies the difference between yīnggāi bù and bù yinggāia, claiming that they both can have an epistemic reading.
a. Yīnggāi
bú huì yǒu fănduì (č̃ yī) pànjué de fălü
Must
not can exist against (this one) judgment DE legal
tiáowén.
regulation
'There should not be a law against this sentence'.
'It will not be possible that there is a law against this'.

(Wang 2003: 157)

b. Bù yīnggāi huì yǒu fănduì (č̃ yī) pànjué de fălù̀

not Must can exist against (this one) judgment DE legal

tiáowén.

regulation

'There should not be a law against this sentence'. (idem)

or'It is possible that there will not be a law against this.'

It is important to point out that in both counter-examples where bù (yīng)gāi has an epistemic meaning, a stative predicate occurs. Moreover, (13) can be located in a scenario in which someone is replying to a previous assertion, denying its truth-condition, and therefore it can be interpreted as a speechact modifier (Von Fintel and Gillies 2008), thus shifting from the modal to the illocutionary level. A similar phenomenon is observed in the Possibility domain with bú huì + stative predicate, as I will underline in the next section.

\subsection{Negative prevision and futurity}

As suggested at the end of Section 4, the marker for acquired ability (hui) is not compatible with internal negation. For this reason, hui bù admits only an epistemic reading. Bú hui, on the other hand, expresses Inability, epistemic possibility and Futurity. With temporal value hui can be interpreted as an aspectual marker, expressing "posteriority relative to past, present and future 
time references", 9 and "conferring a stative quality to the situation it is associated with” (Chen and Saillard 2011). This stative quality of huì is particularly relevant also for its modal vs. aspectual reading. In sentences with unspecified temporal references, huì generally forces a future interpretation (Tsang 1981: 155), but with stative predicates bú huì admits only an epistemic reading as in (15):
a. Tā bú huì shì yí gè jŭngchá.
(Tsang 1981: 64)
he not may be one CL policeman
'He may not be a policeman.'
b. $\neq^{`}$ He will not be a policeman.’
[Improbability, epistemic $\neg \diamond$ ]
[futurity]

The same does not hold if the sentence displays a posteriority meaning (due to the presence of a future reference and of a perfective marker, as in relative future sentences). It must be noted that, in this case, stative verbs acquire a process meaning, as in (16).

(16) Míngtiān kāihuì yāzhù jiù bú huì luàn le. Tomorrow meeting steady then not will disorder FP

'In tomorrow's meeting there will not be any trouble if the situation can be controlled.'

[futurity]

(Tsang 1981: 168)

Whereas the reading of bú hui depends also on the actionality of the main predicate, with internal negation (normally found in interrogative form), hui admits only an epistemic reading, as in (17).

(17) Tã huì bù lái ma? (Chung et al. 2007: 168)
He might not come FP
'Is it possible that he will not come?'
[epistemic]

\section{Scopal properties and suppletion strategies}

So far I have outlined how a negative modal expressing a normative concept is generally used only with that specific meaning, as for bù zhŭn/yào which

9 More precisely, Chen and Saillard highlight the aspectual characterization of the modals hui and yào, displaying, respectively, a posteriority and prospectivity feature. 
do not admit epistemic meaning or for bù yīnggāi which in that area is more often found in the form of yīnggāi bù, involving suppletion and negation placement strategies, respectively. Moreover, I have outlined how, for the sake of disambiguation, a negative normative concept must sometimes be expressed by means of a suppletive form. For instance, modals whose prominent negative meaning corresponds to Exemption, (e.g., bixū), cannot express Prohibition. In order to avoid this restriction, we can either implement negation placement (bìxū bù) or resort to Suppletion A (bù yīnggāi) or to Suppletion B (bù kěy̆). In this section I underline that the specific strategy used for each modal can be accounted for with reference to its interaction with negation, which is conditioned by its lexical specification.

\subsection{Switching from prohibition to exemption: suppletion $A$ and $B$}

Due to their scopal properties, modals such as yinggāi or yào (whose negative form is equivalent to 'It ought not to be the case that'), only have scope over negation, therefore they cannot express the meaning of búbi 'it is not necessarily the case that'. In other words, $\square\urcorner$ items will be used only with the pragmatic meaning of $\square\urcorner$ (Prohibition) and, since they can only have scope over negation, ${ }^{10}$ to change this property to $\neg \square$ (Exemption), negation placement is of no help. The only effective way to avoid this restriction is suppletion strategy. Evidence of this property, as outlined by Lü (1942), is provided by the fact that with double negation yinggāi does not shift to the

10 As outlined by Homer (2010: 13), exceptions to this restriction occur as the result of shielding phenomena, for instance with a universal quantifier between the negation and the modal (NEG > EVERY > MODAL). In this case the scope changes from $\square\urcorner$ to $\neg \square$, as in the example below. This feature is cross-linguistically stable, though in order to overscope the quantified subject, in the Chinese equivalent of 'not everyone must + Verb', the negation must be used in combination with the copula shi.

Shēnghuó zhōng búshì měi gè rén dōu yīng páidú. Life in not.to.be every CL person Focus marker should disintoxicate 'In life it is not the case that everybody ought to disintoxicate.'

$=$ it is NOT required that everyone disintoxicate [Exemption]

$\neq$ it is required that everyone NOT disintoxicate [Prohibition]

(Sparvoli 2011: 319) 
domain of Possibility, as should be the case according to the law of interdefinability of modality [and as occurs with búbì in (18)].

(18) Jiăn zhòng búbì chì ròu.

Reduce weight not.necessary not eat meat.

'To lose weight it is not necessary to avoid meat.'

Equivalent to: 'you can eat meat' [shift to Possibility]

With yinggāi the double negation is just an emphatic device to enhance the binding strength of the obligation, as in (19). Therefore bù yinggāi bù corresponds to $\square$ ר, "It ought not to be the case not to", meaning 'should not not to', equivalent to 'should definitely do so'.

(19) Zhōngguórén bù yīnggāi bù zhīdào de shǐshí Chinese.people not should not know DE historical.facts 'The historical facts that every Chinese should definitely know.' Equivalent to: 'you must know' [no shift to Possibility]

As an alternative, in order to express Exemption, we can use markers in the domain of possibility which are logical equivalents of $\neg \square$, thus implementing Suppletion B. But this strategy requires a combination of negation placement and suppletion, as in kěyı̆ bù, néng bù. What counts here, is that néng and kěyı̆, meaning 'it is possible/permissible that', can have scope both over and under negation. And, more precisely, with wide scope they express Impossibility and Prohibition $(\neg \diamond)$, with narrow scope, for participant-external modality, they convey Exemption $\left(\diamond_{\neg}\right)$.

\subsection{Expressing exemption: a specialized suppletion}

As I have suggested above, the implementation of negation placement strategy is conditioned by the lexical specification of the given modal. For instance, bixū, corresponding to 'it is necessarily the case that', can have wide scope, as in: 'it is necessarily the case not to'. Therefore, it can convey the meaning of bù yinggāi. It is sufficient to place the negative marker after it. The nuance is of course different, but the normative concept that it expresses, thanks to negation placement, can be considered as equivalent (20.a-b). Also, as seen in (20.d), there are syntactic limitations to this suppletive form, but in this context this feature is of no relevance. 
(20) a. Bìxū

bú cuòguò. [wide scope $\square$ ]

be.necessary not miss

'(You) must not miss (it)'

b. = Bù yīnggāi cuòguò or = yīnggāi bù cuòguò.

c. Bù yīnggāi cuòguò de shì [wide scope $\square$ ]]

Not should miss DE thing

'The things (you) should not miss'

d. * Yīnggāi bù cuòguò de shì or * Bìxū bù cuòguò de shì

The most marked phenomenon of suppletion takes place with bixū. Its negative forms are in fact completely different morphological units, wúxū, búbì, búyòng, conveying Exemption, viz. "you are free not to". With these anankastic necessity modals, suppletion is implemented only by items which combine negation and modal markers into a single specialized lexical unit. For this purpose resorting to modals having a Speaker-oriented normative source, such as yào, yinggāii, gāi, is not permitted, not even with negation placement. This feature highlights the correlation between suppletion strategy and disambiguation, a cross-linguistically stable factor, that can be extended to all Chinese modals which convey a normative concept (Prohibition/Exemption). It can be condensed in the following principle: Polysemous in the positive form, modals are used with their prominent value in the negative one, a principle that I define as "specialized value of the negative form". Nonetheless, there is an area of ambiguity concerning the modal value of bù yinggāi and bù huì,

\subsection{A transparent scope for the epistemic: negation placement}

The alternative strategy of disambiguation, i.e. negation placement, affects primarily the epistemic yinggāi and hui, whose modal reading is affected also by the actionality of the main verb. With stative verbs, the modal reading is forced towards the epistemic modalities, while with eventive verbs such a restriction does not take place. As a general overview, it can be claimed that:

- With deontic negation, bù yinggāi, there is a negation 'misplacement' (opaque scope);

- With epistemic negation, a negation placement often occurs and shows iconically the semantic scope (as in yīnggāi bù, transparent scope);

- The resort to negation placement is not needed with stative predicates, which force the epistemic reading as in (13) and (15). 


\section{Summary and conclusion}

I would now like to provide a global overview of the phenomena I have described, most of which are well-known facts. I started from the observation that some modals (yingggäi, bìxu, kěyl) are polysemous in assertive sentences, whereas in their negative form they select one modal reading, corresponding to the modality in which they are used as prominent markers. In other words, (i) each modal in the negative form takes its prominent meaning.

For non-epistemic modalities, this phenomenon displays different features, according to the modal domain. For Necessity, it is characterized by pragmatic exclusion, for Possibility by semantic inclusion. In the former, in order to avoid ambiguity with reference to the normative meaning, negative modals convey one specific normative concept, thus enacting suppletion and negation placement mechanisms. In the Possibility domain, aside from the monosemous use of bù kěyl, a cross-modal use of bù néng can be noted. Depending on the presence of circumstantial markers, it expresses either deontic or dynamic modality, behavior that can be accounted for as a semantic inclusion of Permission denial and Failure as subclasses of Impossibility. Similarly, néng bù can express both 'Permission not to' (deontic) and 'Ability to refrain from' (dynamic). I showed that these meanings are logically and pragmatically equivalent (located under the umbrella of Impossibility, bù néng, and 'Possibility not to', néng bù), differing semantically due to the different normative source (Hsieh 2005), and syntactically due to the different transitivity relation (Teng 1977). Based on this, I claim that in Chinese (ii) a negative modal permits different modal meanings only if there is no pragmatic conflict between them, i.e., when there is no ambiguity in what can or must be done.

This can be accounted for in three different: instances:

1) When the ambiguity is between epistemic vs. deontic reading, given that the former expresses only a judgment of the truth value of the proposition under consideration and is not suggesting what should or could not be done (in other words, they are void of prescriptive value);

2) When the ambiguity is between modalities in a relation of hypernymshyponyms, where the former can be a suppletive form of the latter, but not the other way round (as for bù néng vs. bù kĕy̆);

3) When the ambiguity is between equivalents, such as néng bu used as the prominent marker for both 'Possibility not to' and 'Ability to refrain from'. 
In general, it can be said that when a modal sentence is transformed into a negative form, if the modal is not the prominent marker for the modal category underlying it (Figure 2 and 3), then a suppletion takes place. With some modals, in order to shift to a non-prominent modal meaning, a shift of the negation can take place. There is a modal for which suppletion takes place even when it is used with its prominent value. This is a natural class of particular normative modals, characterized by the following features:

a) Narrow scope with reference to negation;

b) Situation-oriented normative source;

c) Normative concept corresponding to Exemption, suggesting that we are Free to do something.

More specifically, in this suppletion form, a Positive Polarity item, bìxū, is replaced by a modal, búyòng, displaying a Negative Polarity behavior (Van der Wouden 1996: 5). Also, here the negative marker is not a sentential negation, but an integral part of the lexical unit itself, confirming the model of local-neg by Teng (1973). For this reason, a third type of suppletion can be described, which resorts to specialized items combining modal and negation in a morphological unit, which I label as Specialized suppletion.

From the semantic perspective, the wide scope of modals such as yinggāi mirrors a property of their prominent modality that is morally connoted necessity (deontic), i.e. dàodé shang yīngdāng 道德上应当 (Gao 1986-1948: In fact, a moral duty inspired by a Speaker's "sense and sensibility" can by no means include the option of release from obligation. This could explain its logical paraphrases: 'it ought to be the case not to' $(\square \neg)$. On the other hand, the anankastic modal bixū is related to a factual necessity, acknowledged as the result of the assessment of a given scenario which can exist on the basis of a contingent situation and of a given goal. Such a duty might be inevitable here and now, but its prescriptivity could easily vanish tomorrow. Its logical paraphrases are: 'it is not necessarily the case that' ( $\square$ ) or b); and 'it is necessarily the case not to' $(\square \neg)$, a particular and more limited use corresponding to 'it ought to be the case not to'. From these features, and based on the phenomena described for (ii), it can be inferred that (iii) a Situationoriented modal can, in particular cases, overlap with a Speaker- or a Subjectoriented one, but not the other way around. In other words, Situation-oriented source is a hypernym of Speaker- and Subject-oriented source. The claim that in the negative forms modals take their prominent value does not imply that it is unique. Some modals are prominent markers for more than one modality (Li 2003:176), thus displaying a multiple prominence. It must be noted that this dual prominence is found between epistemic and non-epistemic 
modalities, that is, between modal notions that do not engender pragmatic conflicts. As I have shown in Section 5, this is the case of bù yinggāai and bú hui, which - depending on the presence of stative predicates, and in a context where the illocutionary intention to confute a previous statement prevails - are ambiguous between an epistemic/deontic or epistemic/futurity reading. This behaviour can be ascribed to the peculiar status of the epistemic category, which is often ambiguous between the modal and the illocutionary level (Von Fintel and Gillies 2008), and between modal and postmodal meaning, such as futurity (Van der Auwera and Plungian 1998).

Adopting these distinctions in the context of Chinese as L2, where tense and aspect must be presented separately from modality, might be of more than some utility. The differentiation between hui conveying epistemic probability and its function as a posteriority aspectual marker might be particularly important for learners whose native language makes use of verbal inflection for future tense (such as French or Italian, resorting to lexical verb + affix), which are used to express these two meanings via different grammatical aspects. Concerning the unique modal value of bù yinggāi (excluding its epistemic reading), a systematic investigation based on the diagnostic criteria outlined by Drubig (2001) can provide a definite answer. For the present, I leave this issue open and simply underline that it has preferably a deontic reading whereas yinggāi bù has an epistemic one. In the context of Chinese as L2, this generalization can provide a consistent guideline and stimulate students to reflect on the interaction of modal and negation. From this perspective, in teaching Chinese as L2, negation can be used as a trigger to reveal the prominent value of a modal, thus hopefully providing an explanation for phenomena that otherwise risk being understood as merely idiosyncratic.

Acknowledgement: I would like to thank Shou-hsin Teng, Chia-Ling Hsieh, Zhao-Hong Han and two anonymous reviewers for the insightful suggestions. Of course, all the mistakes are mine.

Funding: This research was partially funded by MOFA Taiwan Fellowship program. 


\section{Appendix}

Table 1: Negative forms and prominent value in the Necessity domain.

\begin{tabular}{|c|c|c|c|c|c|}
\hline \multirow[t]{4}{*}{ Modality } & \multicolumn{5}{|l|}{ NECESSITY } \\
\hline & \multicolumn{2}{|l|}{ Epistemic } & \multicolumn{3}{|l|}{ Non-epistemic } \\
\hline & & & \multicolumn{2}{|c|}{ Participant-external } & \multirow{2}{*}{$\begin{array}{l}\text { Participant- } \\
\text { internal }\end{array}$} \\
\hline & & & Anankastic & Deontic & \\
\hline Source orientation & SITUATION & SPEAKER & SITUATION & SPEAKER & SUBJECT \\
\hline Usage & Certainty & & Inevitability & Obligation & Need \\
\hline $\begin{array}{l}\text { Prominent marker } \\
\text { Other markers } \\
\text { accepted, in the } \\
\text { declarative form }\end{array}$ & $\begin{array}{l}\text { 一定 } \\
\text { 肯定,该, 应该 } \\
\text { děi 得, 要, }\end{array}$ & $\begin{array}{l}\text { 该, 应该,肯定, } \\
\text { děi 得, 要, } \\
\text { - 定 }\end{array}$ & $\begin{array}{l}\text { 必须, děi 得, } \\
\text { 要, 应该 }\end{array}$ & $\begin{array}{l}\text { 应该, 要, 该 } \\
\text { děi 得, 必须 }\end{array}$ & $\begin{array}{l}\text { 需要 } \\
\text { 要, děi 得 }\end{array}$ \\
\hline External negation & Uncertainty & & Exemption & I & $\begin{array}{l}\text { Release } \\
\text { from need }\end{array}$ \\
\hline Logical notation & & & $\neg \square=\Delta_{\neg}$ & & $\neg \square$ \\
\hline Negative forms of & $\begin{array}{l}\text { 不一定 } \\
\text { 未必 }\end{array}$ & l & Specialized & & 不需要, \\
\hline $\begin{array}{l}\text { prominent marker } \\
\text { Suppletion A }\end{array}$ & $\begin{array}{l}\text { 未必 } \\
\text { / }\end{array}$ & & $\begin{array}{l}\text { suppletion } \\
\text { Not admitted }\end{array}$ & & \\
\hline Suppletion B & 1 & 可能不 & 可以不, 能不 & & 不许要 \\
\hline Specialized suppl. & 1 & 1 & 不用, 不必, 无须 & & \\
\hline Internal negation & Certainty that & & l & Prohibition & $\begin{array}{l}\text { Need } \\
\text { not to }\end{array}$ \\
\hline Logical notation & & & & $\square \neg=\neg 0$ & $\square_{\urcorner}$ \\
\hline $\begin{array}{l}\text { Neg. forms of } \\
\text { prominent marker }\end{array}$ & 一定不 & $\begin{array}{l}\text { 该不, } \\
\text { 应该不, } \\
\text { 肯定不 } \\
\text { 不该/应该 + } \\
\text { Stative Verb }\end{array}$ & & $\begin{array}{l}\text { 不应该, } \\
\text { 不要 }\end{array}$ & 需要不 \\
\hline Suppletion A & l & 1 & & 必须不 & l \\
\hline Suppletion B & I & I & & $\begin{array}{l}\text { 不可以 } \\
\text { 不得 bù dé }\end{array}$ & 1 \\
\hline
\end{tabular}


Table 2: Negative forms and prominent value in the Possibility domain.

\begin{tabular}{|c|c|c|c|c|c|c|}
\hline \multirow[t]{4}{*}{ Modality } & \multicolumn{6}{|l|}{ POSSIBILITY } \\
\hline & \multicolumn{2}{|l|}{ Epistemic } & \multicolumn{4}{|l|}{ Non-epistemic } \\
\hline & & & \multicolumn{2}{|c|}{ Participant-external } & \multirow{2}{*}{\multicolumn{2}{|c|}{ Participant-internal }} \\
\hline & & & Anankastic & Deontic & & \\
\hline $\begin{array}{l}\text { Source } \\
\text { orientation }\end{array}$ & SITUATION & SPEAKER & SITUATION & SPEAKER & SUBJECT & SITUATION \\
\hline Usage & Probability & & Feasibility & Permission & Ability & Accomplishment \\
\hline Prominent marker & 可能 & 会 & 能, 能夠 & 可以, 可 & $\begin{array}{l}\text { 会, } \\
\text { V1 得 V2 }\end{array}$ & $\begin{array}{l}\text { V1 得 V2 } \\
\text { (POT) }\end{array}$ \\
\hline $\begin{array}{l}\text { Other markers } \\
\text { accepted, in the } \\
\text { declarative form }\end{array}$ & 能 & 可 & 可以, 可 & 能 & 能, 可以, 可 & 能 \\
\hline External negation & Improbability & & Impossibility & $\begin{array}{l}\text { Permission } \\
\text { denial }\end{array}$ & Inability & Failure \\
\hline Logical notation & -70 & & -70 & $\neg 0=\square \neg$ & & -0 \\
\hline $\begin{array}{l}\text { Negative forms of } \\
\text { prominent marker }\end{array}$ & 不可能 & 不会 & 不能夠, 不能, & $\begin{array}{l}\text { 不可以, 不可, } \\
\text { 不得 }\end{array}$ & $\begin{array}{l}\text { 不会, } \\
\text { V1 得不 V2 }\end{array}$ & $\begin{array}{l}\text { V1 不 V2, } \\
\text { 不能 }\end{array}$ \\
\hline Suppletion A & l & l & I & 不能, 不行 & I & / \\
\hline Suppletion B & l & l & / & 不应该 & l & l \\
\hline Specialized suppl. & I & I & I & I & I & I \\
\hline Internal negation & Probability tha & it not & $\begin{array}{l}\text { Possibility } \\
\text { not to }\end{array}$ & $\begin{array}{l}\text { Release from } \\
\text { obligation }\end{array}$ & l & $\begin{array}{l}\text { Ability to refrain } \\
\text { from }\end{array}$ \\
\hline Logical notation & $\Delta_{\neg}$ & & $\Delta_{\neg}$ & $\Delta_{\neg}=\neg \square$, & $*_{\neg}$ & $\Delta_{\neg}$ \\
\hline $\begin{array}{l}\text { Neg. forms of } \\
\text { prominent marker }\end{array}$ & 可能不 & 会不 & 能不 & $\begin{array}{l}\text { 可以不, } \\
\text { 能不 }\end{array}$ & *会不 & 能不 \\
\hline Suppletion A & l & l & I & I & l & l \\
\hline Suppletion B & / & l & / & l & l & l \\
\hline
\end{tabular}

\section{References}

Alleton, V. 1984. Les auxiliaires de mode en chinois contemporain. Paris: Editions de la Maison des sciences de l'homme

Beller, S. 2001. A model theory of deontic reasoning about social norms. In J. D. Moore \& K. Stenning (eds.), Proceedings of the Twenty-Third Annual Conference of the Cognitive Science Society (pp. 63-68). Mahwah N): Lawrence Erlbaum.

Chen, X.-W. \& Saillard, C. 2011 Prospective and Posterior aspect in Mandarin Chinese: on the aspectual value of modals yào and huì. Paper presented at the 7 th Conference of the European Association of Chinese Linguistics (EACL-7). Ca' Foscari University, Venice. 
Chung, Y.-S., Huang, S.-L. \& Chen, K.-J. 2007. Modality and modal sense representation in E-HowNet. In Proceeding of the 21st Pacific Asia Conference on Language. Information and Computation PACLIC (pp. 136-145). Seoul National University.

de Haan, F. 1997. The interaction of modality and negation: A typological study. New York: Garland Press.

de Haan, F. 2006. Typological approaches to modality. In W. Frawley (eds.), The expression of modality, 27-69. Berlin-New York: De Gruyter.

Drubig, H. B. 2001. On the syntactic form of epistemic modality. Manuscript. University of Tübingen.

Ernst, T. 2008. Adverbs and positive polarity in MANDARIN Chinese. In M. K.M. Chan \& H. Kang. Columbus (eds.), Proceedings of the 20th North American Conference on Chinese Linguistics (NACCL-20). Ohio: The Ohio State University. Vol. 1, 69-85.

Ernst, T. 2009. Speaker-oriented adverbs. Natural Language and Linguistic Theory 27(3). 497-544. Von Fintel, K. \& Gillies, A.S. 2008. An opinionated guide to epistemic modality. In T. S. Gendler \& J. Hawthorne (eds.), Oxford studies in epistemology, vol. 2 32-62. Oxford: Oxford University Press.

Gao, M.-K.1986 [1948]. Hanyu yufa lun. Beijing: Shangwu yinshuguan.

Giannakidou, A. 1999. Affective dependencies. Linguistics and Philosophy 22. 367-421.

Giannakidou, A. 2001. Varieties of polarity items and the (non)veridicality hypothesis. In J. Hoeksema, H. Rullman, V. Sanchez-Valencia, and T. van der Wouden (eds.), Perspectives on negation and polarity items. Amsterdam: John Benjamins.

Homer, V. 2010. Neg-raising and Positive Polarity: The View from Modals. Manuscript. Horn, L. R. 1989. A natural history of negation. Chicago \& London: The University of Chicago Press. Hsiao, P.-Y. \& Lin, T.-H. J. 2011. A Tripartite Division of Epistemic Modality in Mandarin Chinese. Paper presented at the Symposium on Chinese Syntax and Semantics. Doshisha University, Kyoto.

Hsieh, C.-L. 2005. Modal Verbs and Modal Adverbs in Chinese: an investigation into the Semantics Source. UST Working Papers In Linguistics (USTWPL). 1, 31-58.

Huang, X.-Y. K. 2009. Multiple-modal constructions in Mandarin Chinese: A cartographic approach and an MP perspective. In Yun X. (ed.), Proceedings of the 21st North American Conference on Chinese Linguistics NACCL-21, (2, pp. 524-540). Rhode Island: Bryant University.

Li, J.-X. 1998 [1924]. Xinzhu guoyu wenfa. Beijing: Shangwu yinshuguan.

Li, R.-Z. 2003. Modality in English and Chinese: a Typological Perspective. Boca Raton Florida: DisCom.

Lin, J. \& Tang, C.-C. J. 1995. Modals as Verbs in Chinese: a GB perspective. The Bulletin of Institute of History and Philology 66. 53-105.

Lü, S.-X.2002 [1942]. Zhongguo wenfa yaolüe. Shenyang: Liaoning jiaoyu chubanshe.

Narrog, H. 2012. Modality. Subjectivity. and Semantic Change: A Cross-Linguistic Perspective. Oxford: Oxford University Press.

Nuyts, J. 2001. Epistemic Modality, Language, and Conceptualization: A cognitive-pragmatic perspective. Amsterdam: John Benjamins.

Peng, L.-Z. \& Liu, Y.-B. 2012. Hanyu de zhuguan qingtai he keguan qingtai. Chinese as a Second Language Research (CASLAR) 1-2. 243-265.

Peng, L.-Z. 2007. Xiandai hanyu qingtai yanjiu. Beijing: Zhongguo shehui kexue chubanshe.

Siemund, P. 2001. "Hortative construction”. In M. Haspelmath, E. König, W. Oesterrreicher, \& W. Raible (eds.), Language typology and language universals, 2, 1028-1038. Berlin \& New York: De Gruyter. 
Sparvoli, C. 2011. Deontico e anankastico. Proposta di ampliamento della tassonomia modale basata sull'analisi dei tratti distintivi dei modali cinesi inerenti dovere e necessità. Ph.D. Thesis. Venice: Ca'Foscari University.

Teng, S.-H. 1977. A semantic study of transitivity relations in Chinese. (Monographs on modern linguistics). Taipei: Student Book Co. Ltd.

Teng, S.-H. 1973. Negation and aspect in Chinese. Journal of Chinese Linguistics 1. 14-37.

Tsang, C. L. 1981. A Semantic Study of Modal Auxiliary Verbs in Chinese. Ph.D. Thesis. Stanford University.

van der Auwera, J. \& Plungian, A. V. 1998. Modality’s semantic map. Linguistic Typology 2. 79-124.

van der Wouden, T. 1996. Negative polarity auxiliaries. Paper presented at the PIONIER conference Perspectives on Negation. Groningen.

von Wright, G. H. 1951. An essay on modal logic. Amsterdam: North Holland Publishing Company. von Wright, G. H. 1963. Norm and action. London: Routledge and Kegan Paul.

Wang, L. 1947. [1943]. Zhongguo xiandai yufa. Shanghai: Shangwu yinshuguan.

Wang, S.-I. 2003. Prescription? Prediction? An analysis of Chinese and English modalities: a comparative approach. Ph.D. Thesis. University of Hawaii.

Zhu, D.-X. 1982. YufaJiangyi. Beijing: Commercial Press.

\section{Bionote}

\section{Carlotta Sparvoli}

Carlotta Sparvoli is adjunct Professor of Modern Chinese at the University of Parma and at the University of Modena and Reggio Emilia. In 2012 she was granted a research fellowship from the Italian Ministry of University and Research and won a Taiwan MOFA fellowship. She is Board Member and Secretary of the European Association of Chinese Linguistics (EACL) and of CASLAR. Her major fields of research are the semantics of modal expressions and tonal phonology. 